\title{
STEAM COMPETENCE FOR TEACHERS: FEATURES OF MODEL DEVELOPMENT
}

\author{
Nataliia Morze ${ }^{1}$ \& Oksana Strutynska ${ }^{2}$ \\ ${ }^{1}$ Borys Grinchenko Kyiv University, \\ 18/2 Bulvarno-Kudriavska Str., Kyiv, Ukraine \\ ${ }^{2}$ National Pedagogical Dragomanov University in Kyiv, \\ 9 Pirogova Str., Kyiv, Ukraine \\ ${ }^{1}$ morze@kubg.edu.ua, ORCID 0000-0003-3477-9254 \\ 22o.v.strutynska@npu.edu.ua, ORCID 0000-0003-3555-070X
}

\begin{abstract}
The paper considers approaches to the development of model of STEAM competence for teachers. The concept of STEM/STEAM competence and their components are analyzed. The existing models of STEM/STEAM competence of foreign and Ukrainian researchers are considered, their components are described. The factors affecting the development of STEM competence model for teachers are identified.

Based on the analysis of the considered researches, the authors developed the model of STEAM competence for teachers, defined and described its components. To clarify the structure of the model of STEAM competence for teachers, the authors conducted a diagnostic survey of Ukrainian educators. Its results are analyzed. They confirmed the correctness and completeness of the structure of the proposed model.
\end{abstract}

Keywords: STEM, STEAM, STEM competence, STEAM competence, teachers.

\section{INTRODUCTION}

One of the ways to modernize and upgrade science and mathematics education in the world is the development of STEAM education. The main purpose of its implementation is to empower people through the development of technical and science education (based on the establishment of links between the STEM-industries), taking into account the need to develop the critical and creative thinking skills of pupils and students. It is important to apply this approach from primary school to higher education to provide the nation with four categories of intellectual investments, which include (Siekmann \& Korbel, 2016: 44):

- creative teachers who are able to successfully teach STEAM disciplines; 
- scientists, engineers and IT professionals who investigate and develop the technological progress necessary for the country's economic success and for the solving global problems;

- technologically experienced workers who are able to create, design, maintain and operate complex technological innovations;

- scientifically and technologically literate citizens who can critically research, understand, and respond to challenges to improve the environment.

The development of competencies in the field of STEM is relevant in today's world. In particular, this is reflected in the EU recommendations on the development of key competencies for lifelong learning (Council Recommendation of 22 May 2018 on key competences for lifelong learning, 2018: 3; Recommendation 2006/962/EC of the European Parliament and of the Council, 2006, p. 13).

The basis of STEM-education is the integration of science and mathematical disciplines with the engineering and technical ones - "STEM disciplines" (mathematics, physics, chemistry, biology, engineering, computer science, astronomy, and geography). The prerequisites for the development of competencies in the field of STEM are mathematical competence and basic competencies in science and technology. They are identified in the EU as the keys to lifelong learning.

In accordance with the Law of Ukraine "On Education", mathematical competence and competencies in the field of natural sciences, engineering and technology are also defined as key and should be formed during the acquisition of secondary education (Law of Ukraine «On Education», 2017). The Concept for the development of science and mathematical education (STEM education), approved in 2020, defines the competencies developed by STEM education (The concept of development of natural and mathematical education (STEM education), 2020): cognitive skills; data processing, interpretation and analysis skills; engineering thinking; research skills; algorithmic thinking and digital literacy; creative qualities and innovation; technological skills; communication skills. At the same time, they are not defined as STEM competence. Thus, solving the issue of determining the structure of STEM/STEAM competence is relevant and open for research today. This is especially important for teachers who teach STEM/STEAM subjects.

Paper goal. This paper reviews the results of the research that examined the STEAM competence model development for teachers.

Research methods. The present authors have used the following research methods and tools for the investigation (2020):

- survey;

- interview with Ukrainian educators;

- documents and content analysis;

- analysis of research papers.

108 Ukrainian educators have taken part in the present research. The survey was created during this project which purposed to gain data on the awarness level of Ukrainian educators about STEAM competence, the STEAM competence model and their respective components. 


\section{RELATED WORKS}

The papers of such Ukrainian and foreign researchers as T. Anisimova, N. Balyk, O. Barna, T. Barnaby, C. Baumer, O. Barylnyk-Kurakova, M. Boiko, A. Carnevale, S. Ceylan, T. Corbett, S. Dembitska, C. Dumaresq, H. Firman, L. Hrynevych, H. Jang, I. Kaniawati, P. Korbel, I. Korobova, O. Kuzmenko, M. Melton, V. Oleksiuk, V. Osadchyi, F. Sabirova, B. Sejati, S. Semerikov, K. Seyit, O. Shatunova, G. Shmyger, G. Siekmann, N. Smith, M. Song, B. Soo, A. Zeynep, N. Valko etc. are devoted to the issue of defining the concept of "STEM competence", the development of its structure and models.

According to UNESCO, STEM competence is a person's ability to properly apply the knowledge, and skills of STEM subjects in their daily life, workplace or in the educational context. These competencies should not be limited and developed within the traditional boundaries of separate areas of existing knowledge (e.g., separate physical or digital competence), (Soo, 2019: 11).

Australian researchers G. Siekmann and P. Korbel define in their paper (Siekmann, \& Korbel, 2016) not STEM competence, but the various skills found in the field of STEM. They classify STEM skills as technical because they believe that the purpose of their formation is to increase people's ability to adapt to work and/or life due to the rapid pace of technology development. Thus, according to G. Siekmann and P. Korbel, STEM skills are the ability to produce scientific knowledge (based on mathematical skills) in order to design, create and develop engineering (technical and technological) or scientific products and services (Siekmann, \& Korbel, 2016: 19).

A similar approach is followed by Turkish researchers S. Ceylan, A. Zeynep and K. Seyit. They consider the following STEM skills as the main ones: the ability to solve engineering issues, engineering design, the individual components of digital and social competencies, the ability to match (associative skills), creativity, innovation, interculturalism, flexibility, adaptability, entrepreneurship, communication, and cooperation (Sen, Ay, \& K1ray, 2018: 85).

One of the methods of determining knowledge, skills and abilities in the field of STEM, as well as STEM competence, is to establish a link between professions in science \& technology and the specific components that characterize them.

A. Carnevale, M. Melton, N. Smith were among the first who conducted fundamental research to define the concept of "STEM competence" and its structure. Their research "STEM: Science Technology Engineering Mathematics" (USA, 2011), (Carnevale, Smith, \& Melton, 2011) was based on an analysis of the database of occupations of current employees in the United States called $O * N E T$ (Occupational Information Network), which at that time contained a description of more than 965 occupations and related competencies (cognitive and non-cognitive). The focus of the research was on an analysis of competencies related to the STEM professions. A.P. Carnevale, M. Melton and N. Smith define STEM competence as a set of basic cognitive and non-cognitive competencies associated with the STEM professions (Carnevale, Smith, \& Melton, 2011: 99).

Figure 1 shows the components of STEM competence, according to the structure proposed in (Carnevale, Smith, \& Melton, 2011: 8): 


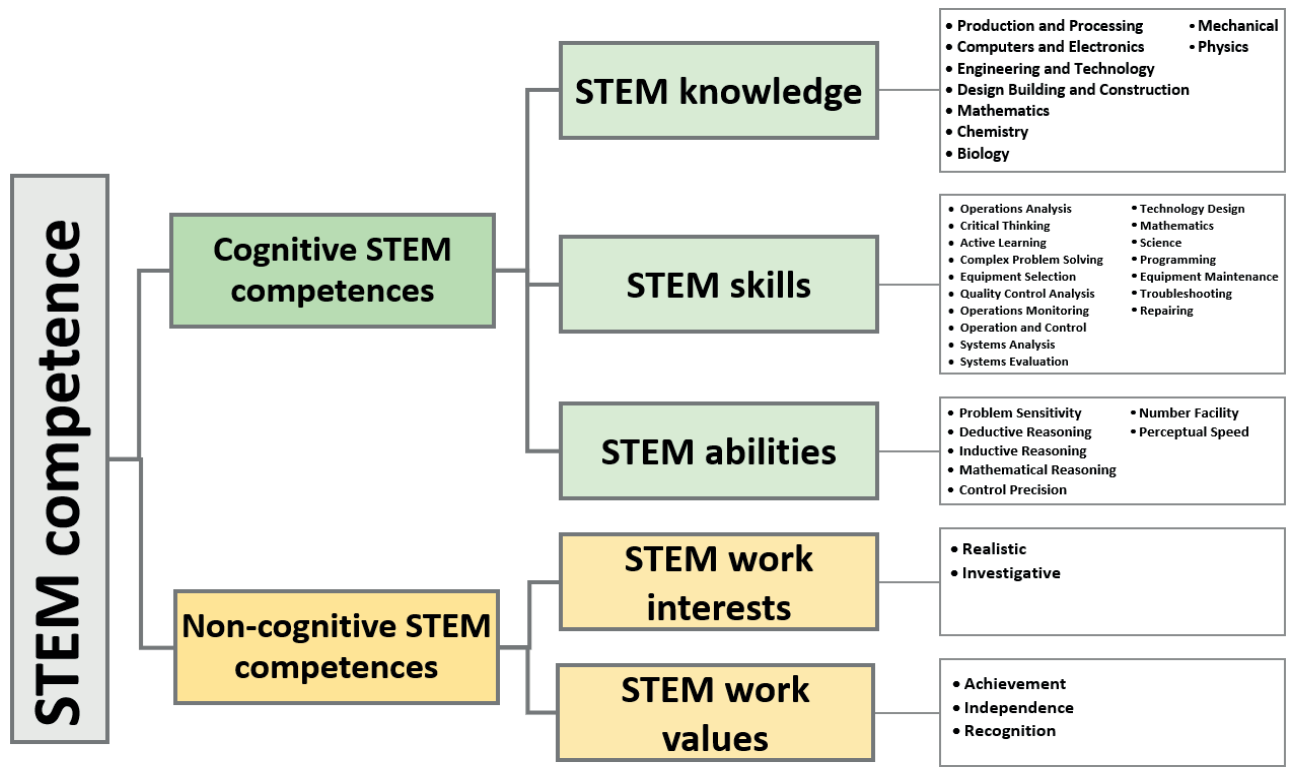

F ig u r e 1. The structure of STEM competence based on A.P. Carnevale, M. Melton, \& N. Smith (USA, 2011)

S o u r c e: Own work based on Carnevale, Smith, \& Melton.

Similar research to determine the components of STEM competence, based on an analysis of the database of occupations O*NET, was also conducted by H. Jang in the United States in 2014 (Jang, 2016).

H. Jang identified 5 groups in the structure of STEM competence. Each of the groups consists of knowledge, skills and activities (Jang, 2016, p. 17):

- solving problems (13 components);

- working with people (18 components);

- working with technology (6 components);

- working with an organizational system (8 components);

- working with resources (7 components).

The researcher explains this division by the fact that STEM working professionals should have competencies that go beyond science, technology, engineering and mathematics. In addition to these competencies, they should be able to solve clearly defined issues (using knowledge of STEM disciplines), communicate with other professionals, understand how they work in organizations, be able to manage time, resources, data, etc. (Jang, 2016: 20). In general, the structure of STEM competence according to H. Jang, contains 52 components. 7 of them belong to knowledge, 18 to skills, with 27 belonging to activities.

Ukrainian researchers have also paid attention to the definition of "STEM competence" and its components.

N.V. Valko (Valko, 2020: 192) defines the STEM competence of a pre-service teacher of sciences and mathematics as an integrative formation, the structure of which includes knowledge, activity and value-motivational components. 
The research (Hrynevych, Morze, \& Boiko, 2020) by L.M. Hrynevych, N.V. Morze and M.A. Boiko smartly defines the components of STEAM competence. According to the authors, these components include the following: mathematical competence, competence in natural science, information and digital competence, civic and social competence, cultural competence, environmental literacy, entrepreneurship and knowledge of a foreign language. The authors considered the components of STEAM competence based on the research of H. Jang (Jang, 2016).

N. Balyk, O. Barna, G. Shmyger and V. Oleksiuk consider STEM competence as a dynamic system of knowledge and skills, ways of thinking, values and personal qualities that determine the ability to innovate: readiness to solve complex issues, critical thinking, creativity, organizational skills, cognitive flexibility, teamwork, emotional intelligence, evaluation and decision making, and the ability of effective interaction and negotiation (Balyk, Barna, Shmyger, \& Oleksiuk, 2018).

The authors developed a STEM competence model for teachers' training and lifelong learning, which is also based on the H. Jang model (Jang, 2016).

The proposed model contains four groups of competencies (skills in problem solving, communication skills, technological \& engineering skills, system skills, and resource management skills). Each of them consists of knowledge, skills and activities. The main components of this model are presented in (Balyk, Barna, Shmyger, \& Oleksiuk, 2018).

At the same time, the basic components of STEM competence of different researchers (Balyk, Barna, Shmyger, \& Oleksiuk, 2018; Jang, 2016; Partnership for $21^{\text {st }}$ Century Skills, 2008) also include the following: an ability to identify the problem; ability to formulate a research task and determine ways to solve it; ability to apply knowledge in different situations; understanding other points of view in problem solving; ability to solve issues out of the ordinary; ability to apply higher order thinking skills. It should be noted that most of these components are components of research competence.

\section{RESEARCH RESULTS}

Analyzing the components of the above structures and models of STEM/ STEAM competence, it should be noted that each of them (in addition to the knowledge, skills and abilities in the field of STEM/STEAM) contains activity and/or value-motivational components.

These components include the following: critical and creative thinking, resource management, teamwork, complex problem solving, engineering thinking, algorithmic thinking, systems assessment, etc. Many of these components are characteristics and personality traits that belong to soft skills. Thus, it is logical to combine them into a separate group.

In addition, the components of the structures of STEM/STEAM competence (analyzed above) include those related to research activities that are characteristics of STEAM subjects. Therefore, research competence will definitely be a component of STEAM competence.

While developing the structure of STEAM competence, it is also necessary to take into account key competencies (civic, social competence, environmental literacy, etc.), 
as great engineering inventions, technical discoveries, significant scientific and technological progress are often used by mankind for destructive purposes that can have undesirable consequences, catastrophes, sometimes on a planetary scale. Therefore, it is extremely important to educate conscious citizens who understand the consequences of their activities.

Based on the analysis of the above structures and models of STEM/STEAM competence, the experience of implementing STEAM education of leading Ukrainian and foreign scientists and practitioners, as well as our own experience, we determined that the components of the structure of STEAM competence include:

- knowledge in the field of STEAM;

- STEAM skills;

- digital competence;

- research competence;

- soft skills;

- some other key competencies.

At the same time, the current issue is to determine the structure of STEAM competence for teachers. The training of teachers who are able to successfully teach the STEAM subjects is extremely important for the formation of students' scientific worldview and the development of the scientific potential of the country as a whole. This is also noted within the research (Siekmann \& Korbel, 2016).

In addition, in the process of developing STEAM competence models, it should be understood that the model for teachers will differ in its components and level of competencies from the corresponding STEAM competence models for scientists, engineers, STEAM skilled workers, etc.

T.I. Anisimova, F.M. Sabirova and O.V. Shatunova believe that in the process of training teachers for STEAM education, it is necessary not only to combine the disciplines and practices of STEAM (natural and engineering sciences, technology, design/ art, and mathematics), but also to include pedagogy and psychology (Anisimova, Sabirova, \& Shatunova, 2020: 208). This means that the structure of the STEAM competence of teachers should include the competence related to their professional activities, i.e., methodological competence. At the same time, the disciplines of the engineering unit should be focused on the development of the design and research competencies of pre-service teachers, in particular the design and modeling skills that are need by them to train engineers (Anisimova, Sabirova, \& Shatunova, 2020: 208). The structure of STEM competence proposed by T. Barnabi, C. Baumer, C. Dumaresk and T. Corbett includes (in addition to content, skills and abilities) teaching practices and assessments, which consist of methodological competence components (such as the development, implementation and analysis of STEM lessons and the appropriate methodology; involving students in the targeted use of pedagogical technologies on the basis of knowledge, skills and abilities in the field of STEM for fulfilling their creative abilities and potential, etc.), (Corbett, Dumaresq, Barnaby, \& Baumer, 2014: 4-5).

B.H. Kim and J. Kim in (Kim \& Kim, 2016: 1918) consider the so-called "teaching competence in STEAM education", which is actually a methodological competence. Its main components include the following: understanding of subjects, methods of 
teaching and learning, motivating students to learn, understanding the learning needs of students, creating educational environment and conditions for learning, assessing student achievement, etc.

Considerations regarding the inclusion of methodological competence in the structure of STEAM competence for teachers are also confirmed by the results of our research (Figure 2).

To clarify the structure of the STEAM competence model for teachers, the authors conducted a diagnostic online survey (using Google Forms) of Ukrainian educators in 2020 (Strutynska, 2020). 108 Ukrainians took part in the survey. Some results of this survey are presented in Figure 2-3.

Q.: Rate on a scale from 0 to 5, how important is each of the proposed components for the development of STEAM competence of teachers ( 0 - not important, 5 -very important).

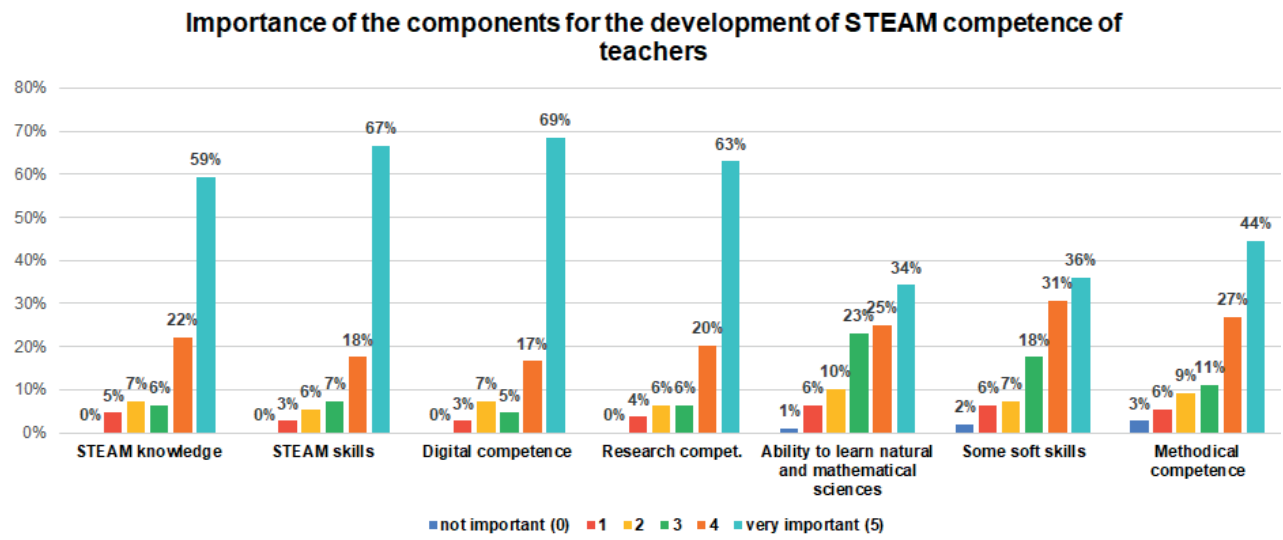

Figure 2. Answers to questions about the importance of components for the development of the STEAM competence of teachers

Source: Own work.

Figure 2 shows that $44 \%$ of respondents rated methodological competence as very important. It also means that educators have an understanding that the teachers of STEAM disciplines must not only have a thorough knowledge, skills and abilities in the field of STEAM, but also have the appropriate methods of teaching them.

Q.: Rate on a scale from 0 to 5, how important are soft skills for the development of STEAM competence of teachers (not important, 5 - very important). 


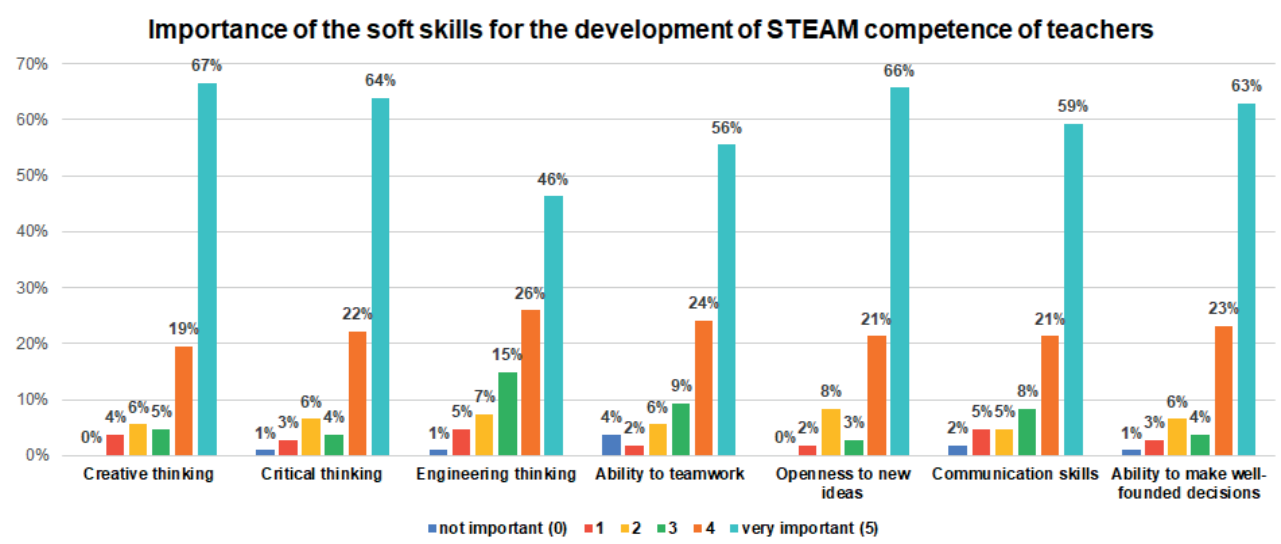

Figure 3. Answers to questions about the importance of soft skills for the development of the STEAM competence of teachers

Source: Own work.

Figure 3 shows that among the most important components for the development of the STEAM competence of teachers, respondents focused on creative and critical thinking (67\% and 64\%, respectively), openness to new ideas $(66 \%)$ and the ability to make informed decisions (63\%). This means that educators have an understanding that for the development of STEAM competence, it is also necessary to develop soft skills.

Thus, based on the analysis of the components, we have developed a generalized model of STEAM competence for teachers (Figure 4):

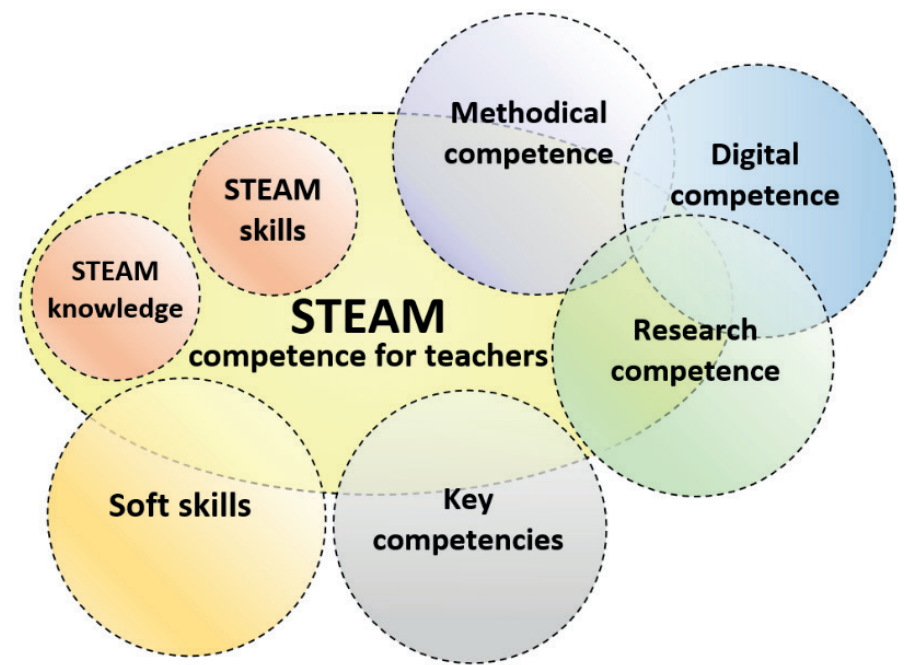

Figure 4. A generalized model of STEAM competence for teachers

Source: Own work.

Table 1 shows the main components of the proposed model: 
Table 1. A generalized model of STEAM competence for teachers

\begin{tabular}{|c|c|}
\hline $\begin{array}{l}\text { The name of } \\
\text { the component } \\
\text { of STEAM } \\
\text { competence }\end{array}$ & The main components include \\
\hline $\begin{array}{l}\text { STEAM } \\
\text { knowledge }\end{array}$ & $\begin{array}{l}\text { mathematics, technology, engineering, design planning, modeling, } \\
\text { natural sciences (physics, astronomy, chemistry, biology, geography), } \\
\text { foreign (English) language, basics of design }\end{array}$ \\
\hline STEAM skills & $\begin{array}{l}\text { mathematical skills; technological skills, engineering design (needs } \\
\text { identification, design, prototyping and model making); equipment } \\
\text { maintenance; the presentation of real world phenomena using a variety } \\
\text { of scientific, mathematical, technological and engineering models; } \\
\text { research of the basic fundamental concepts and principles of science, } \\
\text { engineering, technology, mathematics through connections with other } \\
\text { sectors (history, language, art, culture, etc.); use of mathematical and } \\
\text { scientific principles, considerations for forecasting results, the solving } \\
\text { of technological and technical issues; the design and use of various } \\
\text { resources (data, materials, tools) to safely and effectively solve prob- } \\
\text { lems that require the integration of concepts, methods and skills from } \\
\text { different disciplines; monitoring }\end{array}$ \\
\hline $\begin{array}{l}\text { Research } \\
\text { competence }\end{array}$ & $\begin{array}{l}\text { an ability to identify the problem; ability to formulate a research task } \\
\text { and determine ways to solve it; activity planning; ability to research } \\
\text { and compare; ability to apply knowledge in different situations; un- } \\
\text { derstanding other points of view in solving problems; ability to solve } \\
\text { a problem out of the ordinary; verification and experimental confir- } \\
\text { mation of research results; engineering and design thinking, systems } \\
\text { analysis, systems evaluation }\end{array}$ \\
\hline $\begin{array}{l}\text { Methodical } \\
\text { competence }\end{array}$ & $\begin{array}{l}\text { understanding the principles of STEAM education as an integrated } \\
\text { approach in different disciplines; development of STEAM curricula } \\
\text { (or STEAM disciplines); the development, implementation and } \\
\text { analysis of STEAM lessons; a knowledge of the laws, principles and } \\
\text { methods of teaching \& learning STEAM, including methods that } \\
\text { support higher-order thinking and creative problem solving; motivat- } \\
\text { ing students to learn STEAM, understanding the learning needs of } \\
\text { students, creating learning environments and conditions for learning } \\
\text { STEAM, assessing learning outcomes }\end{array}$ \\
\hline $\begin{array}{l}\text { Digital } \\
\text { competence }\end{array}$ & $\begin{array}{l}\text { a knowledge of computer science required for the subject area, obtain- } \\
\text { ing data from various sources, their analysis, processing and inter- } \\
\text { pretation; algorithmic thinking, the use of digital technologies in the } \\
\text { subject areas of STEAM }\end{array}$ \\
\hline Soft skills & $\begin{array}{l}\text { critical thinking, creative thinking, communication skills, responsibil- } \\
\text { ity, an ability to teamwork, motivate team members, an ability to solve } \\
\text { complex problems, decision making, openness to new ideas, an ability } \\
\text { to use resources management }\end{array}$ \\
\hline
\end{tabular}

Some other key an ability to learn, civic competence, social competence, environmencompetencies tal literacy, entrepreneurship 
STEAM training for teachers of different STEAM disciplines (and, accordingly, the development of their STEAM competence) will differ depending on their specialization that is also confirmed by the results of the research (Figure 5):

Q.: Is the process of STEAM competence development the same for the training of different specialists in STEAM fields (physicists, biologists, mathematicians, etc.) and, accordingly, for the training of teachers of different STEAM disciplines?

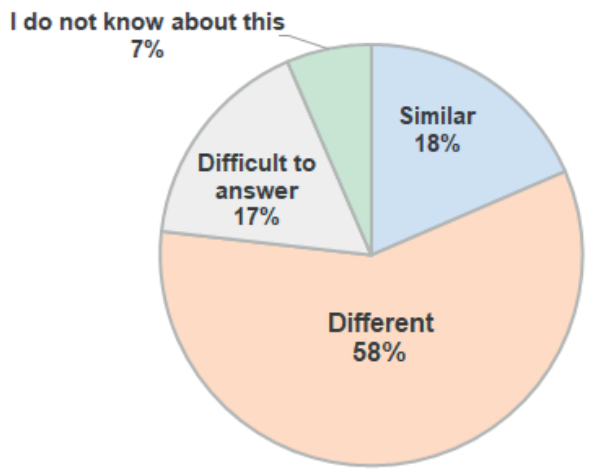

F ig u r e 5. Answers to questions about the development of STEAM competence for the training of different specialists in STEAM industries

Source: Own work.

\section{CONCLUSION}

The development of STEAM education and its trends is important, and this is a priority in Ukraine and the world. The present needs require systematic training in the field of STEM/STEAM education, that is confirmed by the experience and relevant research of the Ukrainian and foreign scientists.

The study result is the development of a model of STEAM competence for teachers. Its components are selected not only based on the relevant Ukrainian and foreign experience, but also are confirmed by the survey of educators. Based on the conducted research, we can make conclusions about the necessity to form the STEAM competence of pre-service teachers who will teach STEAM disciplines and will be able to form the STEAM competence of their students.

Developing the STEAM competence of pupils and students requires administrators and educators to update the content of school and university education in accordance with the requirements of today.

Focusing on the modern labor market, educational professionals should radically update curricular programs, especially those that are directly related to preparing the younger generation for new roles in society. Their mastery of technologies, knowledge and skills can help meet the needs of the digital society in the future.

Since STEAM education is implemented through an interdisciplinary approach in the developing curricular programs at the educational institutions of different levels, then in this regard, it is important to develop educational programs for the training of pre- 
service teachers in the field of STEAM and forming their STEAM competence. This can be implemented through the improvement of educational programs for students who study the natural sciences at pedagogical universities.

Perspectives for further research are:

- an analysis of the integration principles of STEAM disciplines;

- an increase of the awareness of educators regarding the interdisciplinar aspects of the STEM/STEAM education;

- determining of the ways to form STEAM competence to train different specialists in the STEAM fields (physicists, biologists, mathematicians, etc.) and, accordingly, to train teachers of different STEAM disciplines.

\section{REFERENCES}

A n isi mova, T.I., S a bi rova, F.M., \& S h a t u n ov a, O.V. (2020). Formation of Design and Research Competencies in Future Teachers in the Framework of STEAM Education. International Journal of Emerging Technologies in Learning (iJET), 15(02), 204-217. ISSN 1863-0383, https://doi.org/10.3991/ijet.v15i02.11537.

Balyk, N., B arna, O., Sh myger, G., \& Oleksiuk, V. (2018). Model of Professional Retraining of Teachers Based on the Development of STEM Competencies. Proceedings from the ICTERI 2018 ICT in Education, Research and Industrial Applications. Integration, Harmonization and Knowledge Transfer. Vol. II, 318-331. Retrieved from: http:// ceurws.org/Vol-2104/paper_157.pdf ISSN 1613-0073.

B o o n Ng, S o o (2019). UNESCO. Exploring STEM Competences for the $21^{\text {st }}$ Century. 53 p. Retrieved April 27, 2020, from http://learningportal.iiep.unesco.org/en/library/exploring -stem-competences-for-the-21st-century.

Carnevale, A.P., Smith, N., \& Melton, M. (2011). STEM: Science Technology Engineering Mathematics. Executive Summary. Center on Education and the Workforce, Georgetown University (USA), 2011. 15 p. Retrieved April, 23, 2020, from https://files. eric.ed.gov/fulltext/ED525298.pdf.

Corbett, T., Dumares q, C.C., Barnaby, T., \& Baumer, C. (2014). The Framework for integrative Science, Technology, Engineering \& Mathematics (STEM) education endorsement guidelines. Pennsylvania Department of Education. Retrieved April, 29, 2020, from https://www.education.pa.gov/Documents/Teachers-Administrators/Certification \%20Preparation\%20Programs/Specific\%20Program\%20Guidelines/Integrative\%20 Science,\%20Technology,\%20Engineering,\%20Mathematics\%20(STEM)\%20Education\% 20Guidelines.pdf.

Council Recommendation of 22 May 2018 on key competences for lifelong learning. OJ C 189, 04.06.2018, pp. 1-13. Retrieved May 16, 2020, from https://eur-lex.europa.eu/legal -content/EN/TXT/PDF/?uri=OJ:C: 2018:189:FULL\&from=EN.

Hrynevych, L.M., Morze, N.V., \& Boiko, M.A. (2020). Naukova osvita yak osnova formuvannia innovatsiinoi kompetentnosti $\mathrm{v}$ umovakh tsyfrovoi transformatsii suspilstva [Scientific Education as the Basic for Innovative Competence Formation in the Conditions of Digital Transformation of the Society]. Informatsiini tekhnolohii i zasoby navchannia [Information Technologies and Learning Tools], 2020, 77(3), 1-26. https://doi. org/10.33407/ittt.v77 i3.3980 [in Ukrainian]. 
J a n g, H. (2016). Identifying $21^{\text {st }}$ Century STEM Competencies Using Workplace Data. Journal of Science Education and Technology, 25(2), 284-301. https://doi.org/10.1007/s10956 -015-9593-1.

K i m, B.H. \& K i m, J. (2016). Development and Validation of Evaluation Indicators for Teaching Competency in STEAM Education in Korea. Eurasia Journal of Mathematics, Science \& Technology Education, 12(7), 1909-1924. https://doi.org/10.12973/eurasia.2016.1537a.

Legislation of Ukraine. (2017, September 5). Law of Ukraine “On Education” from 05.09.2017. Zakonodavstvo Ukrainy [Legislation of Ukraine]. Retrieved August 20, 2021, from https:// zakon2.rada.gov.ua/laws/show/2145-19 [in Ukrainian].

Legislation of Ukraine. (2020, August 5). The concept of development of natural and mathematical education (STEM education). Order of the Cabinet of Ministers of Ukraine No. 960-p from 5 August 2020. Retrieved August 5, 2021, from https://zakon.rada.gov. ua/laws/show/960-2020-\%D1\%80\#Text [in Ukrainian].

Partnership for $21^{\text {st }}$ Century Skills. Framework for $21^{\text {st }}$ Century Learning. Retrieved May 10, 2020, from http://www.p21.org/our-work/p21-framework.

Recommendation 2006/962/EC of the European Parliament and of the Council of 18 December 2006 on key competences for lifelong learning. OJ L 394, 30.12.2006, pp. 10-18. Retrieved May 15, 2020, from https://eur-lex.europa.eu/legal-content/EN/TXT/PDF/?ur $\mathrm{i}=\mathrm{CELEX}: 32006 \mathrm{H} 0962 \&$ from $=\mathrm{EN}$.

Se n, Ceyla n, Ay, Zey ne p, \& K 1 ray, S eyit (2018). STEM Skills in the $21^{\text {st }}$ Century Education. In: M. Sh elle y, S. A h m et Kir a y (Eds.) Research Highlights in STEM Education. (pp. 81-101). Publisher: ISRES Publishing. Retrieved May 11, 2020, from https:// www.researchgate.net/publication/332574347_STEM_SKILLS_in_the_21_ST_CENTURY_EDUCATION.

Siek m a n n, G. \& Korbel, P. (2016). Defining 'STEM' skills: review and synthesis of the literature - support document 1, NCVER, Adelaide. 56 p. Retrieved April 28, 2020, from https://files.eric.ed.gov/fulltext/ED570655.pdf.

Strut y n ska, O.V. (2020). Teoretyko-metodychni zasady pidhotovky maibutnikh uchyteliv informatyky do navchannia osvitnoi robototekhniky v zakladakh serednoi osvity [Theoretical and methodological principles of training pre-service teachers of computer science for teaching educational robotics in secondary education]: Monograph. Kyiv. Vydavnytstvo NPU imeni M.P. Drahomanova [NPU named by M.P. Drahomanova Press], (Ukraine). 2020. 505 p. [in Ukrainian].

Valko, N.V. (2020). Systema pidhotovky maibutnikh uchyteliv pryrodnycho-matematychnykh dystsyplin do zastosuvannia STEM tekhnolohii u profesiinii diialnosti [The system of training future teachers of natural-mathematical disciplines for the application of STEM-technologies in professional activities] (Doctoral dissertation). Zaporizhzhia (Ukraine), 2020. 510 p. [in Ukrainian]. 